\title{
MEASURING STUDENT LEARNING \\ TO DOCUMENT FACULTY TEACHING EFFECTIVENESS
}

\section{Linda B. Nilson}

Clemson University

Recent research has questioned the validity of student ratings as proxy measures for how much students learn, and this learning is a commonly accepted meaning of faculty teaching effectiveness. Student ratings capture student satisfaction more than anything else. Moreover, the overriding assessment criterion in accreditation and accountability-that applied to programs, schools, and institutions-is student learning, so it only makes sense to evaluate faculty by the same standard. This chapter explains and evaluates course-level measures of student learning based on data that are easy for faculty to collect and administrators to use.

Student ratings are probably the most universally used indicator of teaching effectiveness in faculty reviews. It would be difficult to find an institution that does not place considerable importance on these ratings. Faculty developers have long urged bringing other measures into the equation (Arreola, 2007; Braskamp \& Ory, 1994; Cashin, 1989, 2003; Stark-Wroblewski, Ahlering, \& Brill, 2007), but many institutions still give predominant, if not exclusive, weight to these ratings. Recent research suggests that it is time to replace student ratings or counterbalance them with other indicators. Furthermore, no other academic 
entity except individual faculty is evaluated on student opinions. All the others must produce evidence of student learning. If teaching effectiveness is the ability to motivate and facilitate student learning, it only makes sense to assess faculty, at least primarily, on their students' learning in their courses.

\section{The Validity of Student Ratings}

Over three decades ago, Cohen (1981) defined teaching effectiveness in terms of student learning/achievement and justified using student ratings as a proxy because of their moderately strong positive relationship to student learning: "It [teaching effectiveness] can be further operationalized as the amount students learn in a particular course ... If student ratings are to have any utility in evaluating teaching, they must show at least a moderately strong relationship to this index" (p. 281). However, a great deal of recent evidence shows that this relationship has broken down. At best, it is now weak or nonexistent (Clayson, 2009; Marks, Fairris, \& Beleche, 2010; Weinberg, Hashimoto, \& Fleisher, 2009); at worst, it is negative (Carrell \& West, 2010; Clayson, 2009; Johnson, 2003). Furthermore, student ratings on items most directly related to learning, such as the rigor of the course, the challenge of its content, and required student effort, vary negatively with instructor ratings (Steiner, Holley, Gerdes, \& Campbell, 2006; Weinberg, Fleisher, \& Hashimoto, 2007; others cited in Clayson, 2009).

Another problem with using student ratings to represent student learning is the increasing array of biases plaguing their validity-now over a dozen variables unconnected to learning and mostly outside faculty control, from the instructor's physical attractiveness to his or her public personality to the length of the class meeting (summarized in Nilson, 2012). In fact, students largely form their opinions about an instructor's teaching - the same ones that wind up on the student rating forms-before instruction even begins (Clayson, 2013). In addition, the correlation between expected course grade and student ratings has strengthened from a mild .10 to .30 (Cashin, 1995) to a substantial .45 to .50 (Clayson, 2011), making expected grade one of the best predictors of student ratings.

Finally, a few studies have found the factual accuracy and honesty of ratings to be wanting. In Sproule's (2002) and Stanfel's (1995) classroom research, between nearly half and nearly two-thirds of the students disagreed with the item on their instructor's promptness in returning graded work, even though both researchers returned all graded work at the very next class all semester long. The latter even asked his students to sign a 
document stating that they had received their graded work at the first possible opportunity every time he returned work, and they all signed it. In Clayson and Haley's (2011) survey of students, one-third admitted to "stretching the truth" and 20 percent to lying on their instructor rating forms.

All of the more recent findings on student ratings, those largely representing the responses of millennial undergraduates, back up faculty claims that their ratings suffer when they add rigor and challenge to their course, maintain high grading standards, or have personal characteristics that their students view as "alien." Faculty have also complained about factual misrepresentations in their ratings and student comments. More often than not, administrators and faculty developers have dismissed these grievances, citing decades-old studies that document the connection between student ratings and learning (Cohen, 1981; Feldman, 1989; Marsh, 1984). While calling ratings "a popularity contest" overstates the case, the global items best capture student affect toward and satisfaction with an instructor (Nuhfer, 2010). This explains why the instructor's public personality-specifically, his or her congeniality, self-confidence, enthusiasm, and optimism-explains half to three-quarters of the variance in student ratings (Clayson, 2011). Students strongly prefer energetic, expressive faculty who they believe care about and empathize with them (Clayson, 2011; La Lopa, 2011; Williams \& Ceci, 1997).

\section{How Academic Units versus Faculty are Assessed}

Accrediting agencies do not ask academic units for evidence of student satisfaction. They demand documentation of student learning, whether at the program, school, or institutional level. Similarly, legislators, government agencies, prospective employers of graduates, and the general public are concerned almost exclusively about student learning. Why should individual instructors be evaluated any differently from the units they make up? Given what students value, measures of their satisfaction may or may not belong in faculty reviews, but measures of student learning most definitely deserve a prominent place. After all, the job of an instructor is not to please students but to motivate and facilitate their learning, which corresponds to the mission of every college and university. In fact, learning can work against pleasing students. It often makes them uncomfortable and even dissatisfied for a time because it requires effort, focus, self-examination, acknowledgment of error, and changes in values, beliefs, attitudes, and behavior. Relying on measures of course-level student learning to evaluate the quality of faculty members' 
instruction would bring the indicators of the academic effectiveness into alignment across institutional levels.

\section{Measures of Student Learning on the Course Level}

Few disciplines offer course-specific standardized tests, and those that do (e.g., economics and physics) offer only one or two tests at the introductory level. Student portfolios are cumbersome and time-consuming to evaluate. Members of accreditation teams may have the time to examine a representative sample, but administrators clearly do not. Therefore, these two instruments for measuring student learning-versions of which work on the institutional, school, and program levels-will not work for courses. Faculty need instruments that make data on their students' learning easy to collect and easy to reduce to a single number for each course. The latter is essential to facilitate administrative use in reviews. In addition, for the sake of efficiency, these instruments should do doubleduty as learning enhancements or as major tests or assignments that the faculty would give anyway.

The options presented here meet these conditions. They all come from recent literature and have been used to measure learning, though not all for faculty review. The instruments fall into four classifications determined by when the instructor collects the data-only at the end of the course or at the beginning and the end in a pre- and posttest design-and whether these data are direct or indirect measures of student learning. Table 17.1 displays the instruments as classified. Of course, the most

\section{Table 17.1 Course-Level Measures of Student Learning}

Indirect

End of course only Perceived student learning gains instruments (selfregulated learning activity)

Pre- and posttest
Knowledge surveys (self- regulated learning activity)

\author{
Direct \\ Integrative essay or journal \\ entry (capstone paper \\ or final exam) \\ Targeted essay (capstone \\ paper or final exam) \\ First writing (ungraded) \\ and correction exercise \\ (final exam) \\ First-week essays (ungraded) \\ and "value-added" essay \\ Final exam \\ First-week final exam \\ (ungraded) and final exam
}


scientifically legitimate category measures learning directly in a pre- and posttest design. Only this type of indicator separates course-acquired knowledge and skills from those learned prior to the course.

\section{Indirect, End-of-Course-Only Measures}

This category includes all instruments that ask students to assess their learning in a course at the end of it. They tap students' perceived learning, not their actual learning, which is why they are called "indirect." The two instruments described here can be used by instructors for free and have been validated or are in the process of validation. Student scores on the relevant items can be averaged to reduce the results to a single number.

The Student Assessment of Learning Gains (SALG) survey instrument (at http://www.salgsite.org) is the best known and most widely used of this type. Elaine Seymour, author of Talking about Leaving: Why Undergraduates Leave the Sciences (1997), developed it for chemistry courses in 1997. Ten years later, she and two colleagues revised it for use across the disciplines. The questions ask students to assess their learning gains in a course and the degree to which specific course components helped that learning. The items address different facets of learning: general, understanding concepts, acquiring skills, developing positive attitudes about the course or subject matter, and integrating information. The course components include class activities, assessments, specific learning methods, laboratories, and resources provided. Students respond on a five-point scale, from "no gains" to "great gains" or from "no help" to "great help." Instructors can easily customize the questions to their own courses. Some faculty have submitted their SALG results in their personnel review-a few in lieu of student ratings (Seymour, Wiese, Hunter, \& Daddinrud, 2000).

In validity testing, student scores on the revised version correlated moderately but significantly $(r=.41)$ with student scores on the final exam. In specific topic areas, the correlations between students' SALG scores and the corresponding subsection on the final exam ranged between .49 and zero.

A modest learning enhancement accompanies this instrument. Students examine and assess what they have learned, which is a self-regulated learning activity (Schraw, 1998; Zimmerman, 1998, 2002). As a one-time exercise, it will help them realize that they have indeed learned something, reducing the likelihood that they will complain on their student rating form that they did not learn anything. 
The Transparency in Learning and Teaching (TLT) survey instrument (https://illinois.edu/sb/sec/1428) is so new that it is still two to three years into its pilot phase. As of mid-2012, this phase had surveyed about seventy-five hundred students in seventy-two courses at nine institutions in five countries. The instrument aims primarily to measure the learning impact, as perceived by students, of transparent teaching methods-that is, those that raise students' awareness of the processes by which they are learning. Such methods span a range of instructor actions that help students learn how they learn, including these: explaining in advance the learning goals, outcomes, benefits, and standards of success of the course activities and assignments; letting students help plan classes; telling them about upcoming topics and questions and inviting them to select related material they would like to learn about; gauging their understanding with in-class conceptual and application questions; teaching them brain-based learning principles; having them assess their own work using the instructor's grading criteria; asking them to correct their errors and strengthen the weak areas in their work; and having them record, analyze, and evaluate the process they use to prepare for exams and complete assignments.

The TLT starts out with three general questions about how well students understand course content, how accurately their submitted work reflects this understanding, and the extent to which course work and course activities benefited their learning. These and the other twenty-five perceived-learning items offer a choice of five Likert-type responses. The next nine questions ask students how much the course has helped them acquire or refine certain skills, such as writing effectively, learning how to learn, and applying concepts to practical problems or in new situations. Another nine questions begin with the stem, "As a result of taking this course," and ask students to assess their judgment about opinions different from their own, ideas in general, the reliability of sources, and the like; their confidence in their ability to succeed academically or in this field; and the likelihood of their discussing course-acquired ideas outside class and asking future instructors about the learning benefits of course components. The final four perceived-learning items address miscellaneous issues, such as whether students understand what successful work is in the course and how much the instructor valued them as students.

Most of the transparent teaching methods are standard activities and assignments for helping student develop self-regulated learning skills (Wirth, 2008; Zimmerman, 1998, 2002). Therefore, in a course that has these skills among its learning outcomes and uses these teaching methods, the TLT instrument can serve at least two purposes. First, it can help 
students assess their progress in developing these skills and the impact of these skills on their learning in the course. If a course incorporates enough of these teaching methods, it can indeed build self-regulated skills. Second, the TLT should be able to measure differences in students' perceived learning against baseline courses without such methods.

Weaknesses. Of course, perceived learning is not actual learning. In addition, students are not always good judges of their learning and abilities. The literature on student self-assessment, as meta-analyzed by Falchikov and Boud (1989), reports that students tend to rate their skills and the quality of their work higher than faculty rate the same student performances. Students' self-assessments are especially inflated among nonscience and introductory-level students. Others have found that students' perceived learning is unrelated to their actual learning but is related to the grade they expect to receive (Weinberg, Fleisher, \& Hashimoto, 2007; Weinberg et al., 2009). Similarly, students in the Wabash study failed to perceive how much they had learned as measured by several standardized tests (Bowman, 2011; Porter, 2012). To explain the disjuncture between self-reported and actual learning, Porter proposed and found considerable evidence for the belief-sampling model of survey response, which hypothesizes that students base their self-reports on how many beliefs, feelings, and memories about learning related content they can easily access. The more recollections they have, the greater the learning gains reported, which accounts for why perceived learning correlates with students' academic ability, interest in the subject matter, and experiences in their major.

\section{Indirect, Pre- and Posttest Measures}

Knowledge surveys, classic examples of this type of measure, are useful because their results vary with student learning (Nuhfer \& Knipp, 2003; Wirth \& Perkins, 2005, 2008). They ask students to rate how confident they are that they can answer questions or perform tasks covering the course content and skills. Students choose from three or four levels of confidence. (Examples of suitable geology questions and tasks, each labeled by the required cognitive operation, are at http://serc.carleton.edu NAGTWorkshops/assess/knowledgesurvey/examples.html.) Knowledge surveys also claim the scientific legitimacy of pre- and posttest measures because the instructor administers the same survey at the beginning and end of the course. A course score representing student learning can be calculated by finding the average difference in pre- and posttest confidence ratings across items or by using the more refined methods in the 
section below on direct, pre- and posttest measures. Because knowledge surveys make students reflect on their learning, as do the indirect, end-ofcourse-only measures above, they also have some additional value as a self-regulated learning activity.

Weaknesses. As an indirect measure of student learning based on student perceptions, knowledge surveys have the same validity problem as the indirect, end-of-course-only measures. When students come into a course, most of them, especially nonscience introductory-level students, are overly confident about what they know and can do. At the end of the course, however, they may underestimate what they know and can do and perform better on the final exam than their knowledge survey results would predict. Wirth and Perkins (2008) recorded this pattern in at least one course. Either distortion will lead to underestimating the amount of student learning in a course.

\section{Direct, End-of-Course-Only Measures}

One major advantage of direct, end-of-course measures of learning, whether end-of-course-only or pre- and posttest, is that they can double as a final exam or capstone assignment. Of course, they should reflect the ultimate (end-of-course) student learning outcomes of the course, if not some mediating outcomes as well. So if the ultimate outcomes of a management course on decision modeling are to diagnose a real-world managerial problem, devise multiple solutions, and evaluate them to select the best, this is exactly what the final assessment instrument should have students do, mostly likely for a given case study. Instructors can report their students' learning as the average numerical score (grade in percentage terms) of the final exam or capstone assignment.

The literature suggests two other approaches to measuring end-ofcourse learning. One is the integrative essay or journal entry in which students review all the course material and draw their own conclusions about the most important things they learned and the value of this material to them now and in the future (Atlas, 2007). A more concrete, applied alternative is to place students in a real-world situation they are likely to face soon and ask them how they would use the course material. For example, a job interviewer asks them to describe the most important things they learned in the course and to demonstrate their skills in applying these things (Weimer, 2007).

Weaknesses. As with any other end-of-course-only measure, it is impossible to identify and "remove" the course-related knowledge that students already had coming into the course. In addition, instructors can 
stack the grading and the results to ensure their students do well. Peer reviewers might want to see the questions that the students answered on the grading rubric and some sample essays.

\section{Direct, Pre- and Posttest Measures}

From a scientific standpoint, these measures are the gold standard because they can remove students' precourse knowledge from the endof-course assessment. They entail an assessment at the beginning of the course, the pretest, and the same or very similar assessment at the end, the posttest. Both of these presumably reflect the course's learning outcomes. In Griffiths's (2010) version, she gives her students in her Miscarriage of Justice course the pretest the first week of the semester in the form of an ungraded writing assignment. She asks them to define key concepts, cite important statistics, describe processes, and do other things that they generally will not be able to do accurately until they complete the course. Then for the final, she asks the students to think of themselves as professors of the course and to critique and grade their first-week assignments. Their specific task is to write a letter to their "preclass self" correcting errors, poor reasoning, and misconceptions and to supply accurate answers to the questions.

Anthropology professor John Coggeshall (personal correspondence, 2010-2011) gives his students a first-week, ungraded writing assignment that asks them to take a position, from strongly agree to strongly disagree, on seven statements-some true but most commonly believed mythsand to justify their stand in a sentence or two. For example, one statement claims that the arrival of the Europeans was responsible for Native Americans developing complex societies and another that agriculture and animal domestication radically improved most human lives. At the final exam, he returns these assignments and has his students critique and rewrite four of their original answers, drawing on the course material for supporting evidence and describing how and why their thinking has changed, if it has. He calls these second, much longer essays "valueadded," and he scores them on the quality of the evidence students incorporate to justify their end-of-course position. This criterion reflects his most important ultimate learning outcome.

Another option, which may be more suitable for science, technology, engineering, and mathematics courses, is to give students the final exam in class the first week, calling it an ungraded diagnostic exam, and again as the regular final at the end of the course. During the first week, students need little time to complete the test. If an instructor informs them afterward 
that they just took the final exam, they will try to remember all they can and watch for relevant material during the course. Faculty who feel uncomfortable with this pre- and posttest arrangement can use a previous final exam as the pretest, although the pre- and posttest comparison will not be pure. The same is recommended for faculty who administer the pretest online and risk their students downloading the document.

For his faculty reviews, Coggeshall simply reports the percentage of his students who buttressed their positions on their value-added essay final with anthropological evidence, and all the reviewing parties honor this approach. In many institutions, the average score on the final exam may serve as adequate evidence of student learning. But to provide true preand posttest results, an instructor must score (though not grade) the pretests in order to determine students' learning gains during the course.

Two ways to calculate these gains are available. The first gives the percentage by which students increased their knowledge of the course subject matter during the course:

Ideal types of social capital $\left(\frac{\text { Average posttest } \% \text {-Average pretest } \%}{\text { Average pretest } \%}\right) \times 100$

Therefore, if the students' average score was 20 percent on the pretest and 75 percent on the final, students increased their knowledge and skills in the subject matter by 225 percent during the course:

$$
\frac{75-20}{20}=55=2.75 \times 100=225
$$

Critics of this method view this result as meaningless (Hake, 1998). They argue that the relevant ratio is the actual average learning gain (posttest minus pretest) to the possible learning gain in the course (100 in the posttest minus the pretest)-that is, how much the students learned of all that they could have learned in the course. This ratio is represented by this equation, which Hake calls the "average normalized gain":

$$
\frac{(\text { Average posttest } \% \text { - Average pretest } \%) \times 100}{(100 \%-\text { Average pretest } \%)}
$$

Given the same average percentage scores as above, students learned 68.75 percent of the knowledge and skills that they could have learned in the course:

$$
\frac{(75-20)}{(100-20)}=\frac{55}{80}=.6875 \times 100=68.75
$$


Obviously it is important that instructors state the calculation they are using and interpret the results correctly for their reviewers.

\section{Conclusion}

Institutions have good reason to shift from student ratings to measures of student learning to assess the teaching effectiveness of their faculty. Not only have student ratings lost their validity as proxy measures of learning, but programs, schools, and entire institutions gain or lose their accreditation and their legitimacy with their stakeholders on the basis of their students' learning. Shouldn't faculty be evaluated on the same criteria as the units they constitute?

None of the measures of course-level student learning examined here are perfect, though direct, pre- and posttest measures are probably the least flawed. Any of them can be slanted in the instructor's favor, but to an extent, so can the indicators of student learning used by programs, schools, and institutions; they can be set to increase the likelihood of meeting expectations. No measure of anything as complex as student learning will be perfect, but we can do better by our faculty than to assess their teaching effectiveness using a measure that is no longer related to student learning.

\section{REFERENCES}

Arreola, R. A. (2007). Developing a comprehensive faculty evaluation system: A guide to designing, building, and operating large-scale faculty evaluation systems (3rd ed.). San Francisco, CA: Jossey-Bass.

Atlas, J. L. (2007, June/July). The end of the course: Another perspective. Teaching Professor, 3.

Bowman, N. A. (2011, April 11). The validity of college seniors' self-reported gains as a proxy for longitudinal growth. Paper presented at the annual meetings of the American Educational Research Association, New Orleans, LA.

Braskamp, L. A., \& Ory, J. C. (1994). Assessing faculty work: Enbancing individual and institutional performance. San Francisco, CA: Jossey-Bass.

Carrell, S. E., \& West, J. E. (2010). Does professor quality matter? Evidence from random assignment of students to professors. Journal of Political Economy, $118(3), 409-432$.

Cashin, W. E. (1989). Defining and evaluating college teaching (IDEA Paper No. 21). Manhattan: Center for Faculty Evaluation and Development, Kansas State University. 
Cashin, W. E. (1995) Student ratings of teaching: The research revisited (IDEA Paper No. 32). Manhattan: Center for Faculty Development and Evaluation, Kansas State University.

Cashin, W. E. (2003). Evaluating college and university teaching: Reflections of a practitioner. In J. C. Smart (Ed.), Higher education: Handbook of theory and research (pp. 531-593). Dordrecht, Netherlands: Kluwer Academic.

Clayson, D. E. (2009). Student evaluations of teaching: Are they related to what students learn? A meta-analysis and review of the literature. Journal of Marketing Education, 31(1), 16-30. Retrieved from http://jmd.sagepub .com/content/31/1/16.full.pdf +html

Clayson, D. E. (2011). A multi-disciplined review of the student teacher evaluation process. Retrieved from http://business.uni.edu/clayson/Ext/SET Summary2011.doc

Clayson, D. E. (2013). Initial impressions and the student evaluation of teaching. Journal of Education for Business, 88, 26-35. doi:10.1080/08832323 .2011 .633580

Clayson, D. E., \& Haley, D. A. (2011, Summer). Are students telling us the truth? A critical look at the student evaluation of teaching. Marketing Education Review, 21, 101-112.

Cohen, P. A. (1981). Student ratings of instruction and student achievement: A meta-analysis of multisection validity studies. Review of Educational Research, 51, 281-309.

Falchikov, N., \& Boud, D. (1989). Student self-assessment in higher education: A meta-analysis. Review of Educational Research, 59(4), 395-430.

Feldman, K. A. (1989). The association between student ratings of specific instructional dimensions and student achievement: Refining and extending the synthesis of data from multisection validity studies. Research in Higher Education, 30, 583-645.

Griffiths, E. (2010). Clearing the misty landscape: Teaching students what they didn't know then, but know now. College Teaching, 58, 32-37.

Hake, R. R. (1998). Interactive-engagement versus traditional methods: A six thousand-student survey of mechanics test data for introductory physics courses. American Journal of Physics, 66(1), 64-74.

Johnson, V. E. (2003). Grade inflation: A crisis in higher education. New York: Springer-Verlag.

La Lopa, J. M. (2011). Student reflection on quality teaching and how to assess it in higher education. Journal of Culinary Science and Technology, 9(4), 282-292.

Marks, M., Fairris, D., \& Beleche, T. (2010, June 3). Do course evaluations reflect student learning? Evidence from a pre-test/post-test setting. Riverside: 
Department of Economics, University of California, Riverside. Retrieved from http:/ffaculty.ucr.edu/ mmarks/Papers/marks2010course.pdf

Marsh, H. W. (1984). Students' evaluations of university teaching: Dimensionality, reliability, validity, potential biases, and utility. Journal of Educational Psychology, 76, 707-754.

Nilson, L. B. (2012). Time to raise questions about student ratings. In J. E. Groccia \& L. Cruz (Eds.), To improve the academy: Resources for faculty, instructional, and organizational development, Vol. 31 (pp. 213-228). San Francisco, CA: Jossey-Bass.

Nuhfer, E. B. (2010). A fractal thinker looks at student ratings. Retrieved from http://profcamp.tripod.com/fractalevals10.pdf

Nuhfer, E. B., \& Knipp, D. (2003). The knowledge survey: A tool for all reasons. In C. Wehlburg \& S. Chadwick-Blossey (Eds.), To improve the academy: Resources for faculty, instructional, and organizational development, Vol. 21 (pp. 59-78). Bolton, MA: Anker.

Porter, S. R. (2012). Self-reported learning gains: A theory and test of college student survey response. Research in Higher Education, 54, 201-226. doi:10.1007/s11162-012-9277-0

Schraw, G. (1998). Promoting general metacognitive awareness. Instructional Science, 26, 113-125. Retrieved from http://www.springerlink.com/content /w88410214g78445h/

Seymour, E. (1997). Talking about leaving: Why undergraduates leave the sciences. Boulder, CO: Westview Press.

Seymour, E., Wiese, D. J., Hunter, A., \& Daddinrud, S. M. (2000, March 27). Creating a better mousetrap: Online student assessment of their learning gains. Paper presented at the national meetings of the American Chemical Society Symposium, Using Real-World Questions to Promote Active Learning, San Francisco, CA. Retrieved from http:/www.salgsite.org/docs /SALGPaperPresentationAtACS.pdf

Sproule, R. (2002). The underdetermination of instructor performance by data from the student evaluation of teaching. Economics of Education Review, 21, 287-295.

Stanfel, L. E. (1995). Measuring the accuracy of student evaluations of teaching. Journal of Instructional Psychology, 22(2), 117-125.

Stark-Wroblewski, K., Ahlering, R. F., \& Brill, F. M. (2007). Toward a more comprehensive approach to evaluating teaching effectiveness: Supplementing student evaluations of teaching with pre-post learning measures. Assessment and Evaluation in Higher Education, 44(5), 539-556. Retrieved from http://www.tandfonline.com/doi/pdf/10.1080 102602930600898536 
Steiner, S., Holley, L. C., Gerdes, K., \& Campbell, H. E. (2006). Evaluating teaching: Listening to students while acknowledging bias. Journal of Social Work Education, 42, 355-376.

Student Assessment of Learning Gains (SALG) survey instrument. (n.d.). Retrieved from http://www.salgsite.org

Transparency in Learning and Teaching survey instrument. (n.d.). Retrieved from https://illinois.edu/sb/sec/1428

Weinberg, B. A., Fleisher, B. M., \& Hashimoto, M. (2007). Evaluating methods of evaluating instruction: The case of higher education (NBER Working Paper No. 12844.) Retrieved from http://www.nber.org/papers/w12844

Weinberg, B. A., Hashimoto, M., \& Fleisher, B. M. (2009). Evaluating teaching in higher education. Journal of Economic Education, 40(3), 227-261. Retrieved from http://dx.doi.org/10.3200/JECE.40.3.227-261

Weimer, M. (2007, February). Helping students take stock of learning. Teaching Professor, 4.

Williams, W. M., \& Ceci, S. J. (1997). How'm I doing? Problems with student ratings of instructors and courses. Change, 29(5), 13-23.

Wirth, K. R. (2008, November 19-21). A metacurriculum on metacognition. Keynote address presented at the National Association of Geoscience Teachers Workshops: The Role of Metacognition in Teaching Geoscience, Carleton College, Northfield, MN. Retrieved from http://serc.carleton.edu NAGTWorkshops/metacognition/wirth.html

Wirth, K. R., \& Perkins, D. (2005, April 2). Knowledge surveys: The ultimate course design and assessment tool for faculty and students. In Proceedings of the Innovations in the Scholarship of Teaching and Learming Conference, Northfield, MN. Retrieved from hrtp://www.macalester.edw/geology/wirth NWirthPerkinsKS.pdf

Wirth, K. R., \& Perkins, D. (2008, November 19-21). Knowledge surveys. Session presented at the National Association of Geoscience Teachers Workshops: The Role of Metacognition in Teaching Geoscience, Carleton College, Northfield, MN. Retrieved from http://serc.carleton.edu/NAGT Workshops/assess/knowledgesurvey/

Zimmerman, B. J. (1998). Developing self-fulfilling cycles of academic regulation: An analysis of exemplary instructional models. In D. H. Schunk \& B. J. Zimmerman (Eds.), Self-regulated learning: From teaching to self-reflective practice (pp. 1-19). New York: Guilford.

Zimmerman, B. J. (2002). Becoming a self-regulated learner: An overview. Theory into Practice, 41(2), 64-70. 